OPEN ACCESS

Edited by:

Valerie Purvin,

Midwest Eye Institute, United States

Reviewed by:

Mark Paine,

Royal Brisbane and Women's

Hospital, Australia

Essam Mohamed Elmatbouly Saber,

Benha University, Egypt

*Correspondence:

Aki Kawasaki

aki.kawasaki@fa2.ch

Specialty section:

This article was submitted to

Neuro-Ophthalmology,

a section of the journal

Frontiers in Neurology

Received: 03 June 2019

Accepted: 22 July 2019

Published: 19 August 2019

Citation:

Udry M, Kardon RH, Sadun F and Kawasaki A (2019) The Tadpole Pupil:

Case Series With Review of the

Literature and New Considerations.

Front. Neurol. 10:846

doi: 10.3389/fneur.2019.00846

\section{The Tadpole Pupil: Case Series With Review of the Literature and New Considerations}

\author{
Morgane Udry ${ }^{1}$, Randy H. Kardon ${ }^{2}$, Federico Sadun ${ }^{3}$ and Aki Kawasaki ${ }^{1 *}$ \\ ${ }^{1}$ FondationAsile des Aveugles, Department of Biology and Medicine, Hôpital Ophtalmique Jules Gonin, University of \\ Lausanne, Lausanne, Switzerland, ${ }^{2}$ Department of Ophthalmology and Visual Sciences, lowa City VA Center of Excellence \\ for the Prevention and Treatment of Vision Loss, University of lowa and Veterans Affairs Hospital, Iowa City, IA, United States, \\ ${ }^{3}$ Ospedale Oftalmico Roma, ASL RM1, Rome, Italy
}

Tadpole pupil is a rare phenomenon in which segmental spasm of the iris dilator muscle results in a tadpole-shaped pupil. The pupillary distortion is usually unilateral, lasts several minutes, and can recur in clusters. Any segment of the iris can be affected; thus, for some patients, a different-shaped tadpole pupil is noticed from episode to episode. Tadpole pupil most commonly appears spontaneously in young women. Tadpole pupil is not associated with any systemic disorders, but an ipsilateral Horner syndrome is noted in $46 \%$ of patients. In this article, we have reviewed the existing literature of tadpole pupil, compiling all the published cases in a table and reporting four additional cases to re-examine the clinical profile of this disorder and to consider the different purported mechanisms as means to understand its possible etiology and treatment. The common denominator in the pathophysiology of tadpole pupil is a focal excessive contraction (segmental spasm) of the iris dilator muscle. Based on various proposed pathophysiologic mechanism of tadpole pupil, we can consider potential forms of treatment.

Keywords: pupil, tadpole pupil, pupillary distortion, iris dilator muscle, mydriasis, Horner syndrome

\section{INTRODUCTION}

The term tadpole pupil refers to episodic, focal distortion of the pupillary shape. In 1983, Thompson et al. (1) presented the largest series of 26 patients and described the characteristic profile of tadpole pupil. It most commonly concerns young otherwise healthy women, arises spontaneously in one eye and disappears in $5 \mathrm{~min}$ or less. The tadpole pupil can be accompanied by a blurring of vision or an unusual sensation in the affected eye or on the ipsilateral side of the face. This segmental spasm of the iris dilator can involve any segment of the iris and is usually unilateral. In their series, two patients had bilateral simultaneous tadpole pupils during one episode and eight patients reported episodes of tadpole pupil that alternated sides. The episodes may recur several times a day for several days or weeks before subsiding spontaneously without leaving any sequelae. Between episodes, the pupil is round and reacts normally to light.

Since the seminal paper of Thompson et al. (1), individual reports of tadpole pupil have appeared in the literature. Various associations and mechanisms have been proposed. In this review, we have compiled all the published cases of tadpole pupil and added an additional four cases to re-examine its clinical profile and consider the different purported mechanisms as means to understand possible etiology and treatment. Written informed consent was obtained for each patient presented in the following paragraphs. 


\section{CASES}

\section{Case 1}

A 47-year-old healthy woman noted painless episodic distortion of her right pupil. The pupil became tear-shaped or oval-shaped then returned to a round shape within 1 min (Figures 1A,B). The peak of the tear shape was slightly different with each episode. These episodes occurred spontaneously several times daily in clusters of 2 to 3 days followed by pauses of weeks to months. The episodes have persisted for over 1 year. Recently, the patient noted right upper eyelid ptosis and a smaller right pupil (Figure 1C).

Ophthalmologic and neurologic examinations were normal except for anisocoria and right upper and lower lid ptosis. Instillation of one drop of $1 \%$ apraclonidine resulted in reversal of anisocoria and subtle retraction of the right upper lid, confirming a right oculosympathetic defect.

The patient's episodes of pupillary distortion were diagnosed as tadpole pupil. The anisocoria and lid ptosis were pharmacologically confirmed as a right Horner syndrome, which, though recently noticed by the patient, was apparent on old photographs about 1 year before the onset of tadpole pupil. Imaging studies of the head, neck, and chest were negative.

\section{Case 2}

A 41-year-old healthy woman noted painless episodic distortion of her left pupil (Figure 2A).The pupillary distortion occurred three to four times in 1 week and each episode lasted $<1$ min without other accompanying symptoms. No other episodes have occurred in the year since onset.

Past medical history revealed high myopia and myopic maculopathy of the right eye. She had undergone refractive surgery 11 years ago.

The patient had previously noticed a smaller pupil in her left eye. A review of old photographs dated this anisocoria to 15 years prior (Figure 2C). Ophthalmologic examination was normal except for an anisocoria with left pupillary miosis (Figure 2B). The palpebral fissures were symmetric. Instillation of topical $1 \%$ apraclonidine resulted in reversal of the anisocoria. A diagnosis of left tadpole pupil and a chronic left Horner syndrome was made.

\section{Case 3}

A 42-year-old healthy woman noted painless episodic distortion of her right pupil accompanied by blurry vision in her right eye. The episodes lasted $1 \mathrm{~min}$ or less. She also noted that the pupillary distortion frequently occurred in a different clock sector with each episode (Figure 3A). The episodes recurred weekly for 4 months, then became more occasional and resolved about 2 years after onset.

She also complained of dizziness upon standing in the past year and had had two syncopal episodes. There was no history of asymmetric or patchy sweating.

The neurologic and ophthalmologic examinations were normal except for anisocoria with right pupillary miosis (Figure 3B). The palpebral fissures were symmetric. No anhidrosis was noted. The left pupil demonstrated a poor constriction to light stimulation, and at the slit lamp, sectoral palsy of the iris sphincter muscle was observed. Instillation of dilute $(0.125 \%)$ pilocarpine in both eyes caused left pupillary constriction consistent with cholinergic hypersensitivity of the left but not right pupil. Topical $1 \%$ apraclonidine had no effect on either pupil. A diagnosis of right tadpole pupil and left tonic (Adie) pupil was made.

\section{Case 4}

A 32-year-old healthy man was presented with three to four episodes of spontaneous painless left pupillary distortion associated with mild visual blurring in the previous 2 months. Each episode lasted about $1 \mathrm{~min}$. During one episode, he took a self-photograph and showed it to his neuroophthalmologist (FS), who confirmed a tadpole-shaped pupil. The episodes remitted several months and recurred.

His past medical history revealed only retinal laser treatment to both eyes for a retinal break 3 years previously.

Examination showed an anisocoria with left pupillary miosis and left upper lid ptosis $(1 \mathrm{~mm})$. The onset of anisocoria could not be confirmed from old photographs. Testing with topical apraclonidine did not show any dilation of the smaller left pupil, and the anisocoria remained unchanged. A diagnosis of left tadpole pupil was made. While a concomitant left Horner syndrome was suspected on clinical grounds, sympathetic denervation hypersensitivity was not demonstrated.

\section{DISCUSSION}

To search the literature about tadpole pupil, we used the Medline (PubMed) using the term "tadpole pupil," "pupillary distortion," and "iris dilator spasm" without restriction of publication date. We also reviewed the reference lists from retrieved articles to find articles not revealed by database search. Abstracts from meeting proceedings were not included.

Tadpole pupil is an episodic pupillary distortion resulting in a tadpole-shaped pupil. It is a rare condition, first described in 1912 by Erlenmeyer (2) and termed by Thompson et al. in 1983 (1). At present, only 43 cases have been described in the literature (39 reported previously and 4 additional cases presented in this article) (1, 3-14) (Table 1). Similar to the Thompson et al. series, we have found that the majority of patients with tadpole pupil are women (34/43, 79\%). Likewise, they are relatively young with a median age at onset of 35.5 years old; the range is between 22 and 48 years old. More recently, however, pediatric cases (two patients age 2 years and one patient age 12 years) have been reported $(7,11,13)$.

Tadpole pupil is usually unilateral (40/43, 93\%), and rarely bilateral $(10,13)$. Most of the time, the same eye is affected with each episode, though Thompson et al. found that the side of the tadpole pupil switched in 6 of 26 patients (23\%). The tail of the tadpole shape (the peaked or pulled segment) can involve any segment of the iris and the affected segment can vary with each episode, leading to a changing tadpole shape in 16 of 43 patients (37\%). Nine patients (20\%), however, demonstrated the same distortion of shape with every episode. In 18 patients (41\%), the history and observation could not definitively determine if the tadpole shape changed or not. 
A

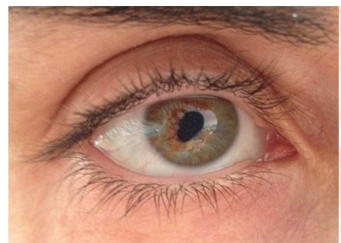

B

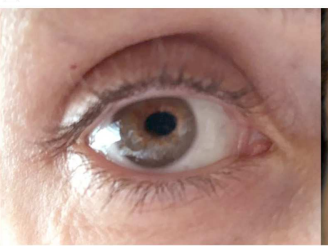

C

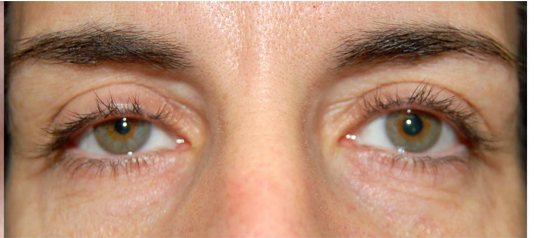

FIGURE 1 | (A,B) Right eye of patient 1 during two episodes of tadpole pupil. Note the oval-shaped deformation of the pupil. (C) Between episodes, an anisocoria with a smaller right pupil and right upper lid ptosis was noted.

FIGURE 2 | (A) Left eye of patient 2 during one episode of tadpole pupil. Note the tear-shaped deformation of the pupil. (B) Between episodes, examination showed
an anisocoria with left pupillary miosis. (C) The anisocoria had been noticed by the patient for 15 years, as shown in this photograph taken 15 years previously.
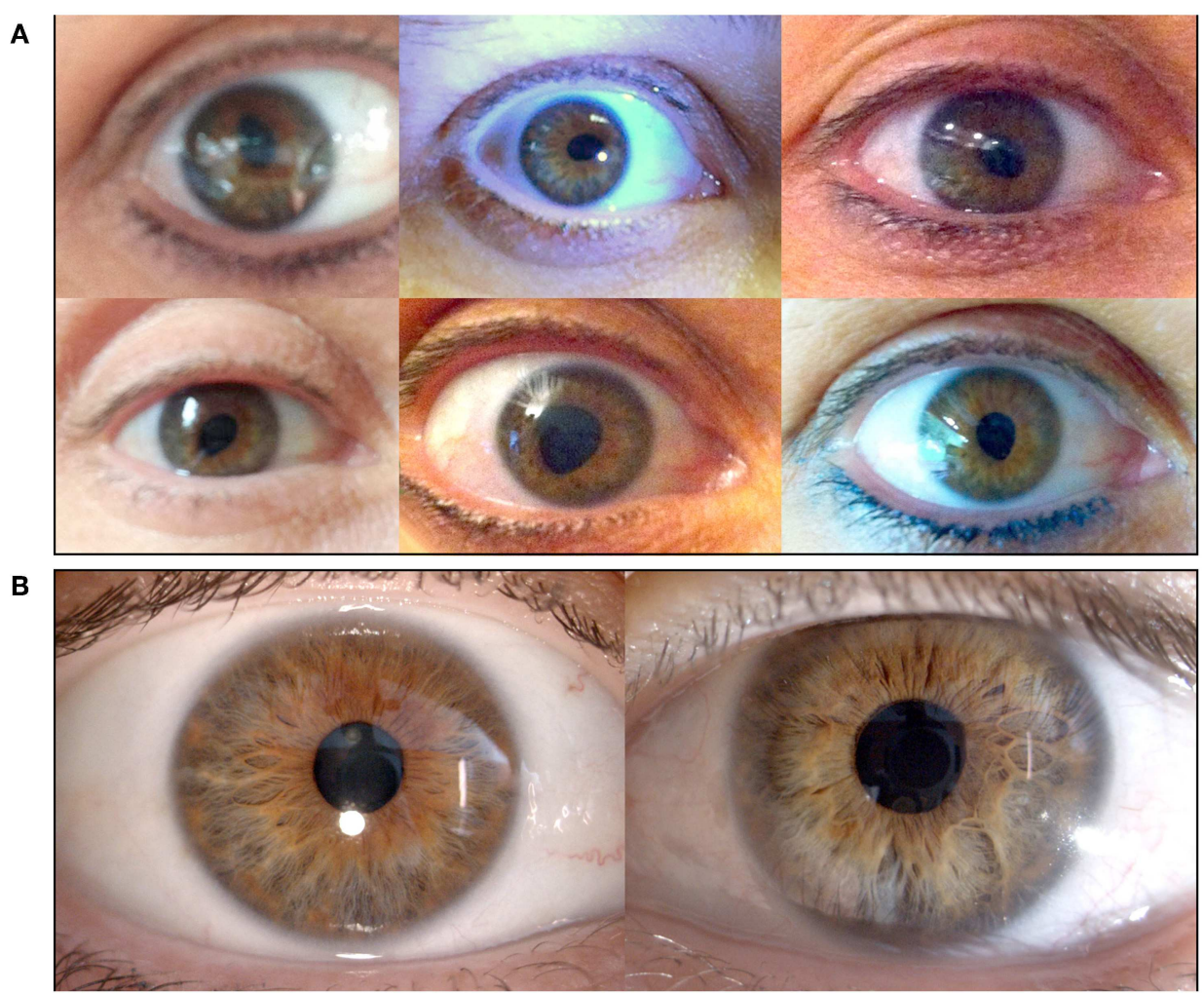

FIGURE 3 | (A) Right eye of patient 3 during different episodes of tadpole pupil. This patient experienced painless episodic distortion of her right pupil accompanied by blurry vision. The pupillary distortion varied with each episode. (B) Between episodes, the patient demonstrated an anisocoria with a smaller right pupil; however, the larger left pupil was poorly reactive to light. Dilute pilocarpine testing (not shown) revealed cholinergic hypersensitivity of the left pupil indicating a left Adie pupil.

The duration of each episode is short, 5 min or less in 34 of $43(79 \%)$ and $15 \mathrm{~min}$ or less in 37 of $43(86 \%)$. Longer episodes are distinctly unusual. The pupillary distortion appeared spontaneously in 39 of 43 patients (91\%) and was accompanied by a blurring of vision or an unusual sensation in the affected eye or on the ipsilateral side of the face in 31 of $43(72 \%)$. 
TABLE 1 | Summary of tadpole pupil cases reported in the literature.

\begin{tabular}{|c|c|c|c|c|c|c|c|c|}
\hline Author & Sex/Age & Side & $\begin{array}{l}\text { Duration of } \\
\text { episodes }\end{array}$ & $\begin{array}{l}\text { Frequency of } \\
\text { episodes }\end{array}$ & $\begin{array}{l}\text { Known } \\
\text { trigger }\end{array}$ & $\begin{array}{l}\text { Associated } \\
\text { symptoms }\end{array}$ & $\begin{array}{l}\text { Associated } \\
\text { condition }\end{array}$ & Timing of HS \\
\hline Thompson & $\mathrm{F} / 48$ & L (1xbilat) & $20 s$ & $\begin{array}{l}2 \text { clusters of } 3-5 \\
\text { days with } 8-10 \\
\text { attacks/days }\end{array}$ & & $\begin{array}{l}\text { Blurred vision } \\
\text { /abnormal } \\
\text { periocular } \\
\text { sensation }\end{array}$ & No & \\
\hline Thompson & $\mathrm{F} / 32$ & $\mathrm{R}$ & $5-10 s$ & $\begin{array}{l}\text { From } 2 \text { to a lot of } \\
\text { episodes/day }\end{array}$ & & Blurred vision & No & \\
\hline Thompson & $\mathrm{F} / 47$ & $\mathrm{~L}$ or $\mathrm{R}$ & $10-15 s$ & $\begin{array}{l}\text { From } 1 \text { to several } \\
\text { episodes/day }\end{array}$ & & $\begin{array}{l}\text { Blurred vision } \\
\text { /headache prior to } \\
\text { episodes }\end{array}$ & $\begin{array}{l}\text { Areas of } \\
\text { intermittent } \\
\text { sweating on the } \\
\text { left flank and right } \\
\text { neck }\end{array}$ & \\
\hline Thompson & $\mathrm{F} / 32$ & $\mathrm{R}$ & $<1 \min$ & 2-3 episodes/year & & Blurred vision & & \\
\hline Thompson & M/30 & $\mathrm{R}$ & $1 \mathrm{~min}$ & $\begin{array}{l}\text { Several clusters of } \\
3 \mathrm{~h} \text { with several } \\
\text { episodes }\end{array}$ & & Light-headedness & $\begin{array}{l}\text { Congenital right } \\
\mathrm{HS}\end{array}$ & Before tadpole $d x$ \\
\hline Thompson & F/young & $\mathrm{L}$ & $15 \min$ & $\begin{array}{l}\text { Once Every } 6 \\
\text { months }\end{array}$ & & $\begin{array}{l}\text { Blurred vision /left } \\
\text { orbital pain }\end{array}$ & Possible migraine & \\
\hline Thompson & $\mathrm{F} / 37$ & $\mathrm{R}$ & & & & & Right HS & $\begin{array}{l}\text { At time of tadpole } \\
d x\end{array}$ \\
\hline Thompson & $\mathrm{F} / 35$ & $R(1 \times L)$ & $3-5 \mathrm{~min}$ & $\begin{array}{l}\text { Clusters of } 90 \mathrm{~min} \\
\text { with several } \\
\text { episodes }\end{array}$ & & $\begin{array}{l}\text { Blurred vision } \\
\text { /funny sensation in } \\
\text { the right eye }\end{array}$ & No & \\
\hline Thompson & $\mathrm{F} / 27$ & $\mathrm{R}$ & A few seconds & $\begin{array}{l}\text { Clusters of } 2 \\
\text { weeks with several } \\
\text { episodes/days }\end{array}$ & & No & $\begin{array}{l}\text { Right } \\
\text { postganglionic HS }\end{array}$ & $\begin{array}{l}\text { At time of tadpole } \\
d x\end{array}$ \\
\hline Thompson & $\mathrm{F} / 48$ & $\mathrm{R}$ & $20 \mathrm{~s}$ to $2 \mathrm{~min}$ & $\begin{array}{l}\text { Clusters of 3-4 } \\
\text { days with 15-30 } \\
\text { episodes/day }\end{array}$ & & Blurred vision & $\begin{array}{l}\text { Right } \\
\text { postganglionic HS } \\
\text { / intermittent } \\
\text { sweating over the } \\
\text { medial part of the } \\
\text { right brow }\end{array}$ & $\begin{array}{l}\text { At time of tadpole } \\
\mathrm{dx}\end{array}$ \\
\hline Thompson & $\mathrm{F} / 36$ & $\mathrm{R}$ & $1 \mathrm{~min}$ & $\begin{array}{l}\text { Clusters of } 3 \mathrm{~h} \text { with } \\
10-12 \text { episodes }\end{array}$ & & Blurred vision & No & \\
\hline Thompson & $\mathrm{F} / 39$ & $\mathrm{R}$ & $2 \mathrm{~h}$ & & & Blurred vision & Migraine & \\
\hline Thompson & $\mathrm{F} / 43$ & $L$ & A few seconds & $\begin{array}{l}\text { Either clusters or } \\
\text { single episodes } \\
\text { separated with } \\
\text { long intervals }\end{array}$ & & $\begin{array}{l}\text { Funny sensation in } \\
\text { the left eye }\end{array}$ & No & \\
\hline Thompson & $\mathrm{F} / 33$ & $L$ & & & & Blurred vision & $\begin{array}{l}\text { Probable left } \\
\text { preganglionic HS } \\
\text { /left tonic pupil }\end{array}$ & $\begin{array}{l}\text { At time of tadpole } \\
d x\end{array}$ \\
\hline Thompson & $\mathrm{F} / 30$ & L or $R$ & A few min & $\begin{array}{l}1-3 \\
\text { episodes/month }\end{array}$ & & $\begin{array}{l}\text { Blurred vision } \\
\text { /funny sensation in } \\
\text { the eye }\end{array}$ & No & \\
\hline Thompson & $F / 38$ & $\mathrm{R}$ & & $\begin{array}{l}\text { Very frequent } \\
\text { episodes during } 2 \\
\text { months }\end{array}$ & & $\begin{array}{l}\text { Funny sensation in } \\
\text { the right eye }\end{array}$ & $\begin{array}{l}\text { Tonic pupil in both } \\
\text { eyes }\end{array}$ & \\
\hline Thompson & $F / 24$ & $\mathrm{~L}$ & $1-2 \min$ & $\begin{array}{l}\text { Clusters of } 1 \text { to } \\
\text { several days with } \\
\text { episodes every } \\
5-10 \text { min }\end{array}$ & & Light-headedness & $\begin{array}{l}\text { Left postganglionic } \\
\text { HS/ } \\
\text { probable migraine/ } \\
\text { left tonic pupil }\end{array}$ & $\begin{array}{l}\text { At time of tadpole } \\
d x\end{array}$ \\
\hline Thompson & $\mathrm{M} / 37$ & $\mathrm{~L}$ & $1-2 \mathrm{~min}$ & $\begin{array}{l}\text { Clusters of } 2-3 \\
\text { days with several } \\
\text { episodes }\end{array}$ & & $\begin{array}{l}\text { Blurred vision } \\
\text { /abnormal } \\
\text { sensation in the } \\
\text { ipsilateral face }\end{array}$ & $\begin{array}{l}\text { Left postganglionic } \\
\text { HS / } \\
\text { migraine }\end{array}$ & $\begin{array}{l}\text { At time of tadpole } \\
d x\end{array}$ \\
\hline Thompson & $F / 33$ & L or R & $1 \mathrm{~min}$ & & & Blurred vision & Migraine & \\
\hline
\end{tabular}


TABLE 1 | Continued

\begin{tabular}{|c|c|c|c|c|c|c|c|c|}
\hline Author & Sex/Age & Side & $\begin{array}{l}\text { Duration of } \\
\text { episodes }\end{array}$ & $\begin{array}{l}\text { Frequency of } \\
\text { episodes }\end{array}$ & $\begin{array}{l}\text { Known } \\
\text { trigger }\end{array}$ & $\begin{array}{l}\text { Associated } \\
\text { symptoms }\end{array}$ & $\begin{array}{l}\text { Associated } \\
\text { condition }\end{array}$ & Timing of HS \\
\hline Thompson & F/32 & $\mathrm{R}$ & A few minutes & Frequent episodes & & $\begin{array}{l}\text { Blurred vision } \\
\text { /funny sensation in } \\
\text { the right eye }\end{array}$ & $\begin{array}{l}\text { Right } \\
\text { postganglionic HS } \\
\text { / } \\
\text { migraine }\end{array}$ & $\begin{array}{l}\text { At time of tadpole } \\
d x\end{array}$ \\
\hline Thompson & $F / 44$ & L or R & & Frequent episodes & & $\begin{array}{l}\text { Funny sensation in } \\
\text { the eye }\end{array}$ & $\begin{array}{l}\text { Left postganglionic } \\
\text { HS/migraine }\end{array}$ & $\begin{array}{l}\text { At time of tadpole } \\
d x\end{array}$ \\
\hline Thompson & $\mathrm{M} / 34$ & $\mathrm{R}$ & $<1 \min$ & $\begin{array}{l}\text { Clusters of several } \\
\text { hours with up to } \\
50 \text { episodes }\end{array}$ & & Blurred vision & Possible migraine & \\
\hline Thompson & $\mathrm{M} / 29$ & L or R or bilat & sec-min & $\begin{array}{l}\text { Daily episodes } \\
\text { since } 3 \text { years }\end{array}$ & & $\begin{array}{l}\text { Blurred vision } \\
\text { /funny sensation in } \\
\text { the eye }\end{array}$ & No & \\
\hline Thompson & $F / 46$ & $\mathrm{R}$ & $1 \mathrm{~h}$ & & & & Tonic pupil bilateral & \\
\hline Thompson & M/36 & $L$ & $3-5 \min$ & $\begin{array}{l}\text { Clusters of } 2 \text { days } \\
\text { with several } \\
\text { episodes/days }\end{array}$ & & Blurred vision & $\begin{array}{l}\text { Probable left HS } \\
\text { /migraine }\end{array}$ & $\begin{array}{l}\text { At time of tadpole } \\
d x\end{array}$ \\
\hline Thompson & $\mathrm{F} / 27$ & L or R & $<3 \min$ & $\begin{array}{l}\text { Clusters of } 2 \text { days } \\
\text { with } 1-5 \\
\text { episodes/day }\end{array}$ & & $\begin{array}{l}\text { Funny sensation in } \\
\text { the eye }\end{array}$ & Right HS /migraine & $\begin{array}{l}\text { At time of tadpole } \\
d x\end{array}$ \\
\hline Tang & $\mathrm{M} / 29$ & $R$ & $<1 \min$ & $\begin{array}{l}\text { Since 2-3 months, } \\
\text { only with exercise }\end{array}$ & $\begin{array}{l}\text { Strenuous } \\
\text { exercise }\end{array}$ & Blurred vision & $\begin{array}{l}\text { Right } \\
\text { postganglionic HS } \\
\text { / hypoplastic right } \\
\text { internal carotid } \\
\text { artery }\end{array}$ & Before tadpole $d x$ \\
\hline Balaggan & $F / 32$ & $\mathrm{~L}$ & $3-15 \min$ & $\begin{array}{l}2 \text { clusters of } 3 \\
\text { days with several } \\
\text { attacks per day in } \\
6 \text { months }\end{array}$ & & $\begin{array}{l}\text { Blurred vision / } \\
\text { abnormal } \\
\text { periocular } \\
\text { sensation }\end{array}$ & $\begin{array}{l}\text { Left preganglionic } \\
\text { HS }\end{array}$ & $\begin{array}{l}2 \text { months after } \\
\text { tadpole dx }\end{array}$ \\
\hline Koay & $F / 33$ & $\mathrm{R}$ & A few minutes & $\begin{array}{l}\text { From several } \\
\text { episodes/days to } \\
1 \text { episode every } \\
\text { several weeks }\end{array}$ & & $\begin{array}{l}\text { Periocular } \\
\text { sensation }\end{array}$ & $\begin{array}{l}\text { Right } \\
\text { postganglionic HS }\end{array}$ & $\begin{array}{l}\text { At time of tadpole } \\
d x\end{array}$ \\
\hline Lüke & $\mathrm{F} / 42$ & $\mathrm{~L}$ & $10 \mathrm{~min}$ & & & Blurred vision & Probable left HS & $\begin{array}{l}\text { At time of tadpole } \\
d x\end{array}$ \\
\hline Lüke & $F / 22$ & $\mathrm{~L}$ & A few minutes & & & $\begin{array}{l}\text { Funny sensation in } \\
\text { the left eye }\end{array}$ & $\begin{array}{l}\text { Morbus Charcot- } \\
\text { Marie-tooth / } \\
\text { papillary druse }\end{array}$ & \\
\hline Weir & $M / 2$ & $\mathrm{~L}$ & $45 \min$ & & $\begin{array}{l}\text { During } \\
\text { strabismus } \\
\text { surgery }\end{array}$ & No & No & \\
\hline Kawasaki & F/young & $\mathrm{L}$ & A few minutes & & & No & No & \\
\hline Höh & $F / 44$ & $R$ & $10-15 s$ & $\begin{array}{l}\text { Clusters of 4-15 } \\
\text { episodes/day for } \\
\text { several days with a } \\
\text { break of } 1 \text { year } \\
\text { between the 1st } \\
\text { and 2ndcluster }\end{array}$ & & $\begin{array}{l}\text { Funny sensation in } \\
\text { the right eye }\end{array}$ & No & \\
\hline Vijayara-ghavan & $\mathrm{M} / 19$ & Bilateral & Long & $\begin{array}{l}1 \text { episode during } \\
\text { recurrent seizures } \\
\text { and hyponatremia }\end{array}$ & $\begin{array}{l}\text { Recurrent } \\
\text { seizures }\end{array}$ & No & $\begin{array}{l}\text { Congenital } \\
\text { erythropoietic } \\
\text { protoporphyria/seizu } \\
\text { /hyponatremia }\end{array}$ & \\
\hline Hansen & $F / 12$ & Bilat (or unilat) & $20 \mathrm{~min}$ & $\begin{array}{l}\text { Initially } \\
\text { spontaneously, } \\
\text { then only with } \\
\text { exercise }\end{array}$ & $\begin{array}{l}\text { Physical } \\
\text { exercise }\end{array}$ & No & $\begin{array}{l}\text { Juvenile idiopathic } \\
\text { arthritis }\end{array}$ & \\
\hline
\end{tabular}


TABLE 1 | Continued

\begin{tabular}{|c|c|c|c|c|c|c|c|c|}
\hline Author & Sex/Age & Side & $\begin{array}{l}\text { Duration of } \\
\text { episodes }\end{array}$ & $\begin{array}{l}\text { Frequency of } \\
\text { episodes }\end{array}$ & $\begin{array}{l}\text { Known } \\
\text { trigger }\end{array}$ & $\begin{array}{l}\text { Associated } \\
\text { symptoms }\end{array}$ & $\begin{array}{l}\text { Associated } \\
\text { condition }\end{array}$ & Timing of HS \\
\hline Ladaique & $\mathrm{F} / 39$ & $L$ & & & & & $\begin{array}{l}\text { Left } \\
\text { HS/asymmetric } \\
\text { facial flushing }\end{array}$ & $\begin{array}{l}2 \text { months after } \\
\text { tadpole dx }\end{array}$ \\
\hline Deschasse & $F / 29$ & $L$ & A few min & $\begin{array}{l}\text { From several } \\
\text { times/days to one } \\
\text { episode/week }\end{array}$ & & No & No & \\
\hline Aggarwal & $\mathrm{F} / 2$ & $\mathrm{R}$ & $40 \mathrm{~min}$ & $\begin{array}{l}\text { Recurrent } \\
\text { episodes since } 2 \\
\text { months }\end{array}$ & $\begin{array}{l}\text { Following } \\
\text { waking up }\end{array}$ & No & $\begin{array}{l}\text { Congenital right } \\
\mathrm{HS}\end{array}$ & Before tadpole $\mathrm{dx}$ \\
\hline Udry & $\mathrm{F} / 47$ & $\mathrm{R}$ & $<1 \min$ & $\begin{array}{l}\text { Clusters of 2-3 } \\
\text { days with several } \\
\text { episodes/day }\end{array}$ & & No & Right HS & Before tadpole $d x$ \\
\hline Udry & $\mathrm{F} / 41$ & $L$ & $<1 \min$ & $\begin{array}{l}\text { Clusters of } 1 \text { week } \\
\text { with } 3-4 \text { episodes }\end{array}$ & & No & $\begin{array}{l}\text { Left HS/ } \\
\text { right myopic } \\
\text { maculopathy }\end{array}$ & Before tadpole $d x$ \\
\hline Udry & $F / 42$ & $\mathrm{R}$ & $<1 \min$ & $\begin{array}{l}\text { Weekly episodes } \\
\text { for } 4 \text { months, then } \\
\text { more occasional }\end{array}$ & & Blurred vision & $\begin{array}{l}\text { Left tonic } \\
\text { pupil/dizziness } \\
\text { upon standing for } \\
1 \text { year with } 2 \\
\text { syncopes }\end{array}$ & \\
\hline Udry & M/32 & $L$ & $1 \mathrm{~min}$ & $\begin{array}{l}3-4 \text { episodes in } 2 \\
\text { months }\end{array}$ & & Blurred vision & $\begin{array}{l}\text { Left miosis and } \\
\text { ptosis but no } \\
\text { demonstrated } \\
\text { HS/retinal break }\end{array}$ & \\
\hline
\end{tabular}

F, female; $M$, male; $R$, right; $L$, left; $H S$, Horner syndrome.

The four cases of non-spontaneous pupillary distortion were temporally related to strabismus surgery, morning awakening, physical exercise, and hyponatremia with seizures: Weir et al. presented a 2-year-old boy with a single episode of tadpole pupil occurring during a non-complicated strabismus surgery and lasting $45 \mathrm{~min}$ (7); Aggarwal et al. described a 2-year-old girl with recurrent episodes of right tadpole pupil appearing just after waking up and lasting $40 \mathrm{~min}$ (11); Hansen et al. reported a 12-year-old girl with episodes of bilateral tadpole pupil provoked by physical exercise and lasting $20 \mathrm{~min}$ (13); and Vijayaraghavan et al. presented a 19-year-old boy with a single long episode of bilateral tadpole pupils in a context of recurrent seizures and hyponatremia (10). Of note, these four patients plus two others described by Thompson et al. had episodes of pupillary distortion longer than $20 \mathrm{~min}$ and lasting up to $2 \mathrm{~h}(1,7,10,11,13)$. Such atypical features like pediatric age, identifiable precipitating factor, and long duration suggest that they may represent a different pathophysiologic entity.

The frequency of episodes varies from one episode every few months to 10-50 episodes per day. Episodes of tadpole pupil seem to occur in clusters lasting days to weeks with a variable and often long interval between clusters. In some patients, a cluster recurs after months to years of remission and in others it subsides spontaneously without leaving any sequelae after several months to years of recurrence. Very rarely, the patient undergoes only one cluster $(3 / 44,7 \%)$ or experiences a single episode of tadpole pupil $(3 / 44,7 \%)$ without recurrence.
An ipsilateral oculosympathetic deficit, or Horner syndrome, is the most frequently associated condition and found in 20 of 43 patients with tadpole pupil (46\%; 15 demonstrated and 5 probable), consistent with the finding by Thompson et al. in their series $(11 / 26$ patients, $42 \%)$ (1). For 5 out of 20 patients $(25 \%)$, the Horner syndrome was present before the appearance of tadpole pupil and for 3 patients (15\%), the Horner syndrome developed after the tadpole pupil. Generally, the Horner syndrome was diagnosed concomitantly with the tadpole pupil, probably because the patient never noticed a pre-existing anisocoria. Thus, it is uncertain as to whether the Horner syndrome typically precedes the tadpole pupil or vice versa. Thompson et al. described also a potential association with Adie's pupil ( $4 / 26$ patients, $15 \%)$ and migraines ( $8 / 26$ patients, $31 \%$ ) (1). However, those associations have not been reported in subsequent studies, except for our Case 3, who presented an Adie's pupil in the contralateral eye. None of our patients had migraine.

The pathophysiologic basis of the tadpole pupil remains undefined. Several mechanisms have been proposed but none can explain all the features of the tadpole pupil.

Given the frequent association with Horner syndrome, sympathetic denervation hypersensitivity has been considered to be one mechanism of tadpole pupil. Tang et al. reported a patient who seems to support such a hypothesis. The patient had a right Horner syndrome presumably related to a hypoplastic internal carotid artery. Topical hydroxyamphetamine failed to dilate the Horner pupil in the superotemporal quadrant, indicating 
a segmental postganglionic sympathetic deficit (partial Horner syndrome). Following physical exercise, this segment became excessively contracted and pulled the pupil into a distorted shape. Thus, the focal area of denervation corresponded to the focal segment of iris dilator spasm, presumably due to denervation hypersensitivity to circulating catecholamines during exercise (3). Hansen et al. described a patient in whom bilateral tadpole pupil appeared following physical exercise and they suggested a focal hypersensitivity to circulating catecholamines. However, pharmacologic evidence of sympathetic denervation was not provided (13). A 2-year-old girl with a congenital right Horner syndrome who developed right tadpole pupil upon awakening was reported by Aggarwal et al. The authors suggested that morning cortisol that peaks 20 to $45 \mathrm{~min}$ after awakening is a possible explanation in their patient (11). The hypothesis of segmental denervation with hypersensitivity may explain tadpole pupil following exercise or waking up, and in these rare cases, the distortion of pupillary shape would be expected to be stereotypic because only the denervated segment demonstrates excessive muscular contraction. Also in these patients, one might expect topical apraclonidine to reproduce the tadpole shape as evidence of a focal hypersensitivity reaction.

Though an attractive hypothesis for these specific aforementioned cases, focal denervation hypersensitivity to circulating adrenergic substances would not explain the tadpole pupil phenomenon in those patients without an underlying sympathetic defect. In the physiologic state, we must consider that a focal contraction of the iris dilator muscle occurs either from focal neurogenic stimulation or direct non-neurogenic activation.

Thompson et al. demonstrated that the effector muscle causing the tadpole pupil is the iris dilator and not the iris sphincter. They first confirmed normal pupil light reflex during tadpole distortion as indication of normal iris sphincter function. Thereafter, they applied $10 \%$ viscous phenylephrine, a directacting adrenergic agonist, to a focal area of the corneoscleral limbus and reproduced the tadpole-shaped distortion (1).

The neuronal stimulus to the iris dilator is the sympathetic system. Can sympathetic neurons destined to the eye fire spontaneously and intermittently? Apparently they can. The Pourfour du Petit syndrome refers to spontaneous discharge of oculosympathetic neurons causing episodic unilateral mydriasis, often in association with lid retraction and conjunctival blanching (15). It is the clinical opposite of a Horner syndrome. Except for occasional cases of patients with headache (16-18), the Pourfour du Petit syndrome largely occurs in the setting of cranio-cervical pathology $(19,20)$. In the event of spontaneous oculosympathetic neuronal discharge, one possible mechanism of tadpole pupil is firing of only a few sympathetic fibers. There are, however, no experimental data to indicate that spontaneous sympathetic discharge to the eye can be focal or segmental.

Another possible mechanism for muscle spasm is nonneurogenic activation of the iris dilator muscle. The iris dilator is a smooth muscle. Unlike gastrointestinal or urinary tract smooth muscle in which contractility has autonomic pacemaker properties and gap junction excitation (21), the iris dilator is classified as a multiunit smooth muscle in which each cell is activated directly and independently, like striated muscles $(22,23)$. This organization allows the contraction of a focal portion of the iris dilator. Like striated muscles, the iris dilator receives neural stimulation at the neuromuscular junction (23, 24). However, unlike striated muscles, smooth muscles may respond directly to hormonal stimuli. For example, estrogen and progesterone receptors located on smooth muscles surfaces can influence muscle contractility (25-28). Sex hormone receptors have been demonstrated in the iris of rabbits (29) and humans (30). Thus, we wonder if circulating hormones, while not the principal stimulus, have the capacity to activate the iris dilator muscle. The iris is well vascularized and radially oriented vessels lie alongside the iris dilator muscle fibers. Intermittent dilator muscle stimulation by hormones may explain, in part, the propensity for tadpole pupil to occur in non-menopausal women and to vary in shape and peak from episode to episode. Thompson et al. had noted that 4 of 21 women (19\%) reported tadpole episodes during or around menstrual periods (1). We recognize that the hormonal hypothesis fails to explain the appearance of tadpole pupil in men, children, and post-menopausal women as well as the brief timing of tadpole pupil. It is interesting to note that when tadpole pupil occurs in men, there is a greater association with an external trigger or underlying pathology $(3 / 9,33 \%)$. These have included hypoplastic internal carotid artery (3), strabismus surgery (7), and hyponatremia (10). Further investigations are needed to clarify any potential role of hormones in the development of a tadpole pupil.

The iris dilator, being a multiunit smooth muscle, does not possess autonomic pacemaker contractility. However, Lee et al. have shown that in vitro muscle fibers of the vas deferens, also a multiunit smooth muscle, develop spontaneous contractions after denervation (31). Thus, spontaneous contractility of a denervated iris dilator muscle can be a predisposing factor for why patients with Horner syndrome have a greater risk for developing tadpole pupil compared to the general population. It remains unclear why tadpole pupil, as a manifestation of denervation, is so rare among all cases of Horner syndrome.

How might the proposed causes of tadpole pupil have clinical implications for treatment?

If hormonal influences are clearly associated with the development of clusters of tadpole pupil, for example, occurrence during menses, it may be possible that systemic regulation of estrogen, e.g., oral contraceptive agents or estrogen patch, offers a potential solution to modulating or halting the clusters. In any event, any type of hormonal manipulation must be discussed as empiric therapy with the patient's general internist or gynecologist.

As focal iris dilator spasm is the common final effector to produce a tadpole pupil, application of a topical alpha-1 adrenergic antagonist, like brimonidine, during the attack or during a cluster period can be expected to reverse the tadpole pupil and stop further episodes. Alpha-1 adrenergic antagonists induce a pharmacologic Horner syndrome. In anecdotal trials, we have found that treating a patient with topical brimonidine did abort further episodes of tadpole pupil, as well as another episodic pupillary phenomenon 
called a benign episodic mydriasis ( $\mathrm{RK}$, personal experience and communication). It is not clear if brimonidine will have a similarly favorable effect on tadpole pupil in patients who already have an oculosympathetic defect (Horner syndrome).

Finally, we wish to point out that most persons with tadpole pupil are not impaired by the occasional episodes and thus treatment is generally not necessary.

In conclusion, the tadpole pupil may be a phenomenon having multiple pathophysiologic mechanisms and associations. Because of the high frequency of association with Horner syndrome, we suggest that all persons with tadpole pupil undergo pharmacologic testing for an oculosympathetic

\section{REFERENCES}

1. Thompson HS, Zackon DH, Czarnecki JS. Tadpole-shaped pupils caused by segmental spasm of the iris dilator muscle. Am J Ophthalmol. (1983) 96:467-77. doi: 10.1016/S0002-9394(14)77 910-3

2. Erlenmeyer A. Beschreibung Von Periodischem Auftreten Einerwandernden Pupille. Berlin Klin Wochenschr. (1912) 49:539.

3. Tang RA, Winn TL, Lee KF, Marroquin G, Patchell L, Yeakley JW. Unilateral pupillary distortion: a case report. $J$ Clin Neuroophthalmol. (1985) 5:105-8. doi: 10.1001/archneur.1974.004903700 38003

4. Balaggan KS, Hugkulstone CE, Bremner FD. Episodic segmental iris dilator muscle spasm: the tadpole-shaped pupil. Arch Ophthalmol. (2003) 121:744-5. doi: 10.1001/archopht.121.5.744

5. Koay KL, Plant G, Wearne MJ. Tadpole pupil. Eye. (2004) 18:93-4. doi: 10.1038/sj.eye.6700513

6. Lüke J, Wilhelm H. [Episodic pupillary distortion]. Klin Monatsbl Augenheilkd. (2009) 226:438-9. doi: 10.1055/s-0028-11 09137

7. Weir RE, Hajdu SD, Greaves BP. Transient tadpole pupil associated with primary uncomplicated medial rectus reattachment. J Pediatr Ophthalmol Strabismus. (2010) 47:e1-2. doi: 10.3928/01913913-20100 507-06

8. Kawasaki A, Mayer C. Tadpole pupil. Neurology. (2012) 79:949. doi: 10.1212/WNL.0b013e318266fcdd

9. Höh AE, Beisse F. [Recurrent unilateral pupillary distortion]. Ophthalmol Z Dtsch Ophthalmol Ges. (2014) 111:376-8. doi: 10.1007/s00347-0132944-5

10. Vijayaraghavan R, Philips CA, Choudhury SP. Bilateral tadpole pupils. Neurology. (2016) 86:1074-5. doi: 10.1212/WNL.00000000000 02470

11. Aggarwal K, Hildebrand GD. The tadpole pupil. JAMA Neurol. (2017) 74:481. doi: 10.1001/jamaneurol.2016. 5981

12. Deschasse C, Baudin F, Gabrielle PH, Bron AM, Creuzot-Garcher C. [Spasm of iris dilator muscle or tadpole-shaped pupil]. J Fr Ophtalmol. (2017) 40:522-3. doi: 10.1016/j.jfo.2016.12.019

13. Hansen JK, Møller HU. Is tadpole pupil in an adolescent girl caused by denervation hypersensitivity? Neuropediatrics. (2017) 48:185-7. doi: 10.1055/s-0036-1597614

14. Ladaique M, Kawasaki A. Teaching neuroImages: multiple clinical manifestations of a ganglionic sympathetic defect. Neurology. (2017) 88:e67-8. doi: 10.1212/WNL.0000000000 003641

15. Walsh FB, Hoyt WF. Clinical Neuro-Ophthalmology. 3rd ed. Baltimore, MA: Williams and Wilkins (1969).

16. Collongues N, Labouret P, Speeg C, de Seze J. A case of recurrent facial pain associated with a Pourfour du Petit syndrome: deficit. Without or with Horner syndrome, the tadpole pupil appears to be a benign condition, which itself does not lead to any chronic sequelae nor portends more serious underlying pathology.

\section{AUTHOR CONTRIBUTIONS}

MU, RK, FS, and AK contributed to conception of the manuscript. AK and MU performed literature review and drafted the manuscript. MU created the table and formatted the figures. $\mathrm{AK}, \mathrm{RK}$, and FS provided the original data. AK, MU, RK, and FS revised the draft and reviewed the figures. All authors reviewed and approved the final manuscript. a new entity? Headache. (2014) 54:373-7. doi: 10.1111/head. 12137

17. Evans RW, Garibay A, Foroozan R. Pourfour du Petit syndrome associated with right eye pressure. Headache. (2017) 57:937-42. doi: 10.1111/head. 13059

18. Nadal J, Daien V, Audemard D, Jeanjean L. Pourfour du Petit syndrome: a rare association with cluster headache. Ophthal Plast Reconstr Surg. (2019) 35:e15-6. doi: 10.1097/IOP.00000000000 01281

19. Teeple E, Ferrer EB, Ghia JN, Pallares V. Pourfour Du Petit syndromehypersympathetic dysfunctional state following a direct non-penetrating injury to the cervical sympathetic chain and brachial plexus. Anesthesiology. (1981) 55:591-2.

20. Byrne P, Clough CA. case of Pourfour Du Petit syndrome following parotidectomy. J Neurol Neurosurg Psychiatr. (1990) 53:1014. doi: 10.1136/jnnp.53.11.1014

21. Costanzo LS. Cellular physiology. In: Schmidt W, Cicalese B, editors. Physiology. 5th ed. Philadelphia, PA: Saunders Elsevier (2014). p. 1-44.

22. Raff H. Cell physiology. cell, nerves, muscles. In: Lombard JH, Rusch N J, editors. Physiology Secrets: [Questions and Answers Reveal the Secrets to Understanding Physiology]. 2nd ed. Philadelphia, PA: Hanley and Belfus (2003). p. $1-40$.

23. Sherwood L. Muscle physiology: smooth and cardiac muscle. In: Alexander S, Glubka A, Oliveira L, editors. Human Physiology: From Cells to Systems, 8th ed. Belmont, CA: Brooks/Cole, Cengage Learning (2013). p. 292-300.

24. Seifter J, Sloane D, Ratner A. Musculoskeletal physiology. Smooth muscle. In: Sun B, Scogna KH, editors. Concepts in Medical Physiology. 1st ed. Philadelphia, PA: LippincottWilliams and Wilkins (2005). p. 93-112.

25. Bielefeldt K, Waite L, Abboud FM, Conklin JL. Nongenomic effects of progesterone on human intestinal smooth muscle cells. Am J Physiol. (1996) 271:G370-6. doi: 10.1152/ajpgi.1996.271. 2.G370

26. Salom JB, Burguete MC, Pérez-Asensio FJ, Centeno JM, Torregrosa G, Alborch E. Acute relaxant effects of 17-betaestradiol through non-genomic mechanisms in rabbit carotid artery. Steroids. (2002) 67:339-46. doi: 10.1016/S0039-128X(01)0 0185-4

27. Dambros M, van Koeveringe GA, Bast A, van Kerrebroeck PEV. Relaxant effects of estradiol through non-genomic pathways in male and female pig bladder smooth muscle. Pharmacology. (2004) 72:121-7. doi: 10.1159/0000 80184

28. Hogan AM, Kennelly R, Collins D, Baird AW, Winter DC. Oestrogen inhibits human colonic motility by a non-genomic cell membrane receptor-dependent mechanism. Br J Surg. (2009) 96:817-22. doi: 10.1002/ bjs. 6612 
29. Wickham LA, Gao J, Toda I, Rocha EM, Ono M, Sullivan DA. Identification of androgen, estrogen and progesterone receptor mRNAs in the eye. Acta Ophthalmol Scand. (2000) 78:146-53. doi: 10.1034/j.1600-0420.2000.07800 2146.x

30. Ogueta SB, Schwartz SD, Yamashita CK, Farber DB. Estrogen receptor in the human eye: influence of gender and age on gene expression. Invest Ophthalmol Vis Sci. (1999) 40:1906-11.

31. Lee TJ, Westfall DP, Fleming WW. The correlation between spontaneous contractions and postjunctional supersensitivity of the smooth muscle of the rat vas deferens. J Pharmacol Exp Ther. (1975) 192:136-48.
Conflict of Interest Statement: The authors declare that the research was conducted in the absence of any commercial or financial relationships that could be construed as a potential conflict of interest.

Copyright (® 2019 Udry, Kardon, Sadun and Kawasaki. This is an open-access article distributed under the terms of the Creative Commons Attribution License (CC BY). The use, distribution or reproduction in other forums is permitted, provided the original author(s) and the copyright owner(s) are credited and that the original publication in this journal is cited, in accordance with accepted academic practice. No use, distribution or reproduction is permitted which does not comply with these terms. 